\title{
Promising implications of Tinospora cordifolia utilization and its functional significance: A review
}

\author{
Review Article
}

Khursheed Alam Khan ${ }^{*}$, Shiv Kumar Katiyar ${ }^{2}$, Prabhat K Nema ${ }^{3}$

1. Assistant Professor, College of Horticulture, Mandsaur of R.V.S. Agriculture University, Gwalior, M.P., 2. Professor and Head, Institute of Food Technology, Bundelkhand University, Jhansi, U.P., 3. Professor, Department of Food Engineering, NIFTEM, Sonipat, Haryana.

\begin{abstract}
Tinospora cordifolia (TC) a traditional plant used in Indian Ayurvedic medicine widely. Different parts of this plant such as stem, roots, leaves are used for treatment and control of various health issues as well as an ingredient in functional foods. It possesses many health promoting and protecting properties. The present article is a critical review providing a comprehensive discussion on therapeutic application and functional significance of TC. The aim of this review is to develop a clear understanding of these issues. Specifically coverage in this review are published information in the areas of Diabetic retinopathy, Free radical scavenging, Anti-Diabetic, Cognition enhancing, Antiinflammatory, Anti-allergic, Immunomodulatory and Anti-cancer, Management of Hay Fever, Antioxidant, Hypoglycaemic and Hypolipidaemic, Osteoblasts formation, Immunomodulatory, Immunostimulatory, Protection from Skeletal Muscle Atrophy, Gastroprotective, Antiosteoporotic etc. Uses of TC as plant digestive enzyme and as supplementation in formulation of various functional foods are also compiled for the information and knowledge of food scientists and technologists. The future scope of the review remains in exploiting TC so as to enable new and effective formulation in disease eradication. Further studies are necessary, however, to investigate the best practices for the promising implications of TC utilization and its functional significance.
\end{abstract}

Key Words: Tinospora cordifolia, Giloy, Amrita, Rasayana, Therapeutic, Alkaloids, Anti-cancer.

\section{Introduction}

One of the most common dioecious plants is Tinospora cordifolia (TC). The plant grows up to 1200 metres above sea level in India's tropical belt, from Kumaon to Assam in the north, and across Bihar, West Bengal, Deccan, Konkan, Karnataka, and Kerala in the south. It's a widespread deciduous and dry forest plant that grows over small trees and hedges. (1) In Hindi language, the TC is termed as Giloy, which is known as divine elixir that has kept celestial beings eternally youthful and shielded them from old age (2).

TC is mentioned in Ayurvedic scriptures as a component of many medicinal formulations that have been used to treat many diseases. It is being used to improve overall body immunity and it also has antistress and adaptogen properties $(3,4)$. The reason that this plant is pronounced as "Amrita" in Ayurveda, denotes its significant usage for rejuvenation (5).

In medication, the stems, roots and leaves of TC are used $(6,7,8)$. In Ayurvedic medicine, TC is referred to as "rasayana" which means "nutrient circulation" in

* Corresponding Author:

Khursheed Alam Khan

Assistant Professor,

College of Horticulture,

Mandsaur of R.V.S. Agriculture University,

Gwalior, M.P. India

Email Id: khan undp@yahoo.ca
Sanskrit language. Rasayana was used in enhancing memory, protection from illnesses, enhancing life expectancy, anti-aging and fostering intellect by the ancient Indian physician Charaka, suggesting an immunostimulant action (9) and had been used as an antidiarrheal and antispasmodic agent (10). TC is reported in particular to be used in tribal medicine in different regions of India. In ethno botanical studies undertaken by ethno botanists $(11,12)$, each part of the TC plant has been recorded to be useful.

Several chemical constituents have been identified and purified from various parts of TC including glycoside, phenolics, alkaloid, aliphatic compounds, lactone, terpenoid, lignan, steroid, and polysaccharide. Protein, phosphorus and calcium are abundant in leaves $(13,14)$. Alkaloids, glycosides and flavanoids are abundant in methanol extracts of leaves (15). Alkaloids, terpenoids, protoberberine and polysaccharides are three basic forms of substances that are thought to be effective components of TC $(16,17)$.

\section{Materials and methods}

This review paper was written after reading and comprehending a large number of published research papers on Tinospora cordifolia in national and international journals, books etc. Published data and scientific information on Tinospora cordifolia have been gathered and assessed from diverse sources based on its therapeutic application and functional significance. 
Therapeutic Application and Functional Significance

TC has shown a variety of in-vitro and in-vivo therapeutic evidences, as well as the functional significances. Some of the most significant and notable observations are reported here:-

\section{Management of diabetic retinopathy}

Diabetes mellitus increases the risk of microand macro-vascular disorders such as nephropathy, retinopathy, neuropathy, coronary artery disease, peripheral arterial disease, and stroke (18). If diabetes is not treated correctly, it can lead to anatomical and functional changes in the kidney (19). The most common cause of blindness is diabetic retinopathy. Diabetic STZ-induced rats were treated with TC extract $(250 \mathrm{mg} / \mathrm{kg}$ ) for 24 weeks, substantially lowering blood glucose and glycated haemoglobin in treated rats and preventing the formation of cataracts in treated rats. TC has also provided a protection against the degradation of glutathione and catalase antioxidant enzymes. Destruction of the structure of the pancreatic islets was found in the diabetic population, but not in the treated community. Thus, TC lowers blood glucose and reduces angiogenic and inflammatory mediators, which are distinct indicators of diabetic retinopathy, from over expression (20).

It was also reported that the changes in extracellular matrix components (Chondroitin sulphate/ dermatan sulphate), which play an important role in kidney function and structure, are caused by diabetes. The effect of TC intake on kidney CS (Chondroitin sulphate)/DS (dermatan sulphate) was examined. It has been shown that eating a diet combined with TC has beneficial effects in diabetic patients, and has a positive impact on the kidney's CS/DS metabolism (21).

\section{Free radical scavenging properties}

Free radicals are formed as cells utilize oxygen to produce energy. As discovered by electron paramagnetic resonance spectroscopy, TC exhibits good free radical scavenging properties against reactive oxygen and nitrogen species. During OGD (Oxygenglucose Deprivation), TC attenuates oxidative stress induced cell injury and exerts the above effects at both the levels of cytosolic and gene expression and can be an important therapeutic technique for ischemic brain harm (22). During a study in male albino mice, TC extract was investigated for its potential protective role in the spleen and blood against ochratoxin Ainduced toxicity (OTA). OTA triggers oxidative effects that lead to free radical formation, making it a risk factor for both humans and animals. It is investigated that TC extracts safeguards against oxidative disorder caused by OTA. TC may defend against splenic macrophages and restore intracellular antioxidant potential as a traditional antioxidant (23).

\section{Anti-Diabetic properties}

Insulin is a hormone that aids in the regulation of blood sugar i.e. glucose and insulin resistance (IR) is a condition in which the body's cells do not respond normally to insulin. Since glucose cannot easily reach cells, it accumulates in the blood. Type 2 diabetes may evolve as a result of this.

A research was conducted to examine whether aqueous Tinospora cordifolia stem extract (TCAE) ameliorates insulin resistance caused by high fructose diet and oxidative stress in rats. TCAE medication inhibited a 21.3 percent rise in glucose levels, 51.5 percent insulin, 54.12 percent triglycerides and 59.8 percent glucose-insulin index in fructose-fed rats (24).

In diabetic animals, the anti-hyperglycemic activity of aqueous and alcoholic extracts as well as lyophilized TC powder was examined using different doses of diabetic agents for different durations (21-120 days) in order to determine their efficacy in mild (plasma sugar $>180 \mathrm{mg} / \mathrm{dl}, 21$ days), moderate (plasma sugar $>280 \mathrm{mg} / \mathrm{dl}, 120$ days) and extreme (plasma sugar $>400 \mathrm{mg} / \mathrm{dl}, 60$ days) diabetes mellitus. In the mild diabetes experiment, a median decrease in glucose levels of 70.37 percent was observed in animals receiving $400 \mathrm{mg} / \mathrm{kg}$ TC aqueous extract each day after 3 and 15 weeks of therapy, respectively. In moderate and extreme diabetes conditions, the percent drop in glucose declined dramatically for TC, 48.81 and 0 percent respectively, at comparable time intervals (25).

T C stem-isolated alkaloid rich fraction isoquinoline (AFTC) were examined in vitro and in vivo for insulin-mimicking and insulinreleasing activity. The findings suggest that the alkaloid in TC plays a part in antihyperglycemic activity. AFTC increases postprandial glucose levels by pathways of insulin releasing and insulin-mimicking activity (26).

The daily oral feeding of TC extracts for 40 days and its effect on blood glucose and kidney function concentrations in diabetic streptozotocin (STZ) rats was investigated. It was reported that plasma glucose concentrations were lowered $7.45 \%$ by the ingestion of TC extracts in STZ-diabetic mice (27).

\section{Cognition enhancing properties}

The experiment was undertaken in two groups of rats to examine the effect of TC extracts on cognition. The alcoholic $(200 \mathrm{mg} / \mathrm{kg})$ and aqueous $(100$ $\mathrm{mg} / \mathrm{kg}$ ) extracts from the whole TC plant were administered orally for 15 days. It is reported that TC enhances cognition (learning and memory) in rats (28).

\section{Anti-inflammatory properties}

In albino rats, anti-inflammatory activity of TC was investigated. The animals were administered with Tinospora cordifolia and with acetylsalicylic acid, the generic medicine. In both acute and subacute inflammation models, TC has developed a major antiinflammatory effect. The effect of Tinospora cordifolia on acute inflammation was greater than that of acetylsalicylic acid (29).

In activated human monocytic THP-1 cells, the antioxidant and anti-inflammatory effects of alcoholic and water extracts of TC leaves were evaluated. As experimental models for studying the antioxidant and anti-inflammatory functions of plant extracts, arachidonic acid (AA)- and lipopolysaccharide (LPS)activated human monocytic (THP-1) cells were used. 
Total flavonoid and phenolic material, as well as tinosponone, a TC-specific clerodane-derived diterpene, were present in substantial amounts in TC extracts. In THP-1 cells, both forms of extracts decreased AAinduced ROS generation by increasing catalase enzyme activity. The results show that TC leaf extracts possess antioxidant and anti-inflammatory properties by upregulation of antioxidant enzymes in activated human monocytic (THP-1) cells and attenuation of NF- $\kappa \mathrm{B}$ nuclear translocation (30).

\section{Anti-allergic Properties}

The anti-allergic properties of TC stem aqueous extract were tested for histamine-induced bronchospasm in guinea pigs, capillary permeability in mice and destruction of mast cells in rats. The extract greatly lowered the $5 \%$ histamine aerosol-induced bronchospasm, decreased capillary permeability and decreased the amount of disrupted mast cells in the laboratory animals, respectively (31).

\section{Immunomodulatory and Anti-cancer Properties}

Immunosuppressants, cytotoxic and a number of side effects are reported by the synthetic chemotherapeutic agents available today, which are especially prevalent in cancer chemotherapy. To overcome the undesired effects of cytotoxic chemotherapeutic agents and to maintain good health, botanical-based immunomodulators are also used as complementary or adjuvant treatment. In an experiment, treatment of ascitic sarcoma-bearing mice with complete extract formulation of Tinospora cordifolia and Withania somnifera (20:80) and alkaloid-free polar fraction of Withania somnifera resulted in defence against CP-induced myelo- and immunoprotection, as reported by large increase in white cell counts and titers of hemagglutinating and hemolytic antibodies. In the development of complementary care for cancer chemotherapy, treatment with these compounds would be significant (32).

An experiment was conducted to isolate, elucidate the composition, measure and pharmacologically test secondary Tinospora cordifolia metabolites for anticancer and immunomodulatory activities. Four separate human cancer cell lines, SiHa (human cervical cancer), HT-29 (human colon cancer), CHOK-1 (hamster ovary) and KB (human oral squamous carcinoma) and murine primary cells were tested for the anti-cancer and immunomodulatory activities of different extracts, fractions and isolated compounds of TC. All TC extracts and fractions were active against $\mathrm{KB}$ and $\mathrm{CHOK}-1$ cells, while tinocordiside was active against $\mathrm{KB}$ and $\mathrm{CHOK}-1$ among the pure molecules; palmatine against $\mathrm{KB}$ and HT-29; yangambin against KB cells, but Nformylannonain and 11-hydroxymustakone were active for immunomodulatory activity (33).

It was observed that the administration of Tinospora cordifolia polysaccharide fraction was very effective in decreasing the metastatic potential of B16F-10 melanoma cells. Approximately 72 percent inhibition of the development of metastases in the lungs of syngeneic C57BL/6 mice was observed when the medication was administered concurrently with a tumour challenge. In contrast with untreated control animals, biochemical parameters such as lung collagen hydroxyproline, hexosamines and uronic acids, which are indicators of neoplastic growth, were substantially decreased in treated animals (34).

HeLa cells were exposed to aqueous, methylene chloride, and methanol TC extracts at various doses $(0$, $5,10,25,50$, and $100 \mathrm{~g} / \mathrm{ml})$, cell killing increased dosedependently but dramatically relative to non-drugtreated controls. Methanol and aqueous extracts have almost similar effects. However, as opposed to either methanol or aqueous extract, methylene chloride extract improved the cell killing effect by 2.8 - and 6.8 -fold at 50 and $100 \mu \mathrm{g} / \mathrm{ml}$ respectively. It is observed that the TC destroyed the cells very successfully in vitro, suggesting that it could be used as an anticancer agent (35).

An experiment was conducted to see how in vivo administration of TC alcoholic extract of whole plant affected the proliferation and myeloid differentiation of bone marrow hematopoietic precursor cells in mice. It has been reported that TC can affect the myeloid differentiation of bone marrow progenitor cells as well as macrophage recruitment in response to tumour growth in situ (36).

The cumulative white blood cell count in BALB/c mice was substantially improved after injection of TC stem methanolic extract $(200 \mathrm{mg} / \mathrm{kg}$, i. p., everyday for 5 days) to the mice. It also enhanced bone marrow cellularity and $\alpha$-esterase positive cells, suggesting that stem cells were maturing faster. The TC extract was also found to substantially boost humoral immune response and macrophage activation when given to mice.TC extract is reported to prevent the development of solid tumours and worked in combination with cyclophosphamide to suppress tumours in animals (37).

\section{Management of Hay Fever}

Hay fever, also known as allergic rhinitis, is a form of nasal inflammation caused by the immune system's overreaction to allergens in the air. In a randomised, double-blind, placebo-controlled trial, the effectiveness of Tinospora cordifolia (TC) extract in patients with allergic rhinitis was evaluated. They were verified experimentally and DLC (differential leucocyte count), TLC (total leucocyte count) and nasal smear were performed along with $\mathrm{Hb}$ percent. 100 percent relief from sneezing, 71 percent from nasal pruritus, 69 percent from nasal discharge, 61 percent from nasal obstruction has been recorded with TC treatment (38).

\section{Antioxidant Properties}

The antioxidant properties of $\mathrm{TC}$ roots in alloxan diabetic rats were investigated. Oral administration for 6 weeks of aqueous Tinospoa cordifolia root extract (TCREt) $(2.5$ and $5.0 \mathrm{~g} / \mathrm{kg})$ resulted in a drop in reactive plasma thiobarbituric acid, alpha-tocopherol and ceruloplasmin levels in diabetic alloxane rats. A rise in glutathione and vitamin $\mathrm{C}$ levels 
in alloxane diabetes is also caused by the root extract. The root extract had the best effect at a dosage of $5.0 \mathrm{~g} /$ $\operatorname{kg}(39)$.

It was planned to determine the antioxidant and in vivo genoprotective capacity of the phenolic compounds produced by the Tinospora cordifoliaisolated endophytic fungus (Cladosporium velox). The overall phenolic content was estimated to be $730 \mu \mathrm{g}$ gallic acid equivalent $/ \mathrm{mL}$ in the fungi' ethyl acetate extract. With an IC50 value of $22.5 \mu \mathrm{g} / \mathrm{mL}$, the extract demonstrated strong antioxidant activity in the DPPH scavenging assay. The findings of the study indicate the ability of Tinospora cordifolia-isolated endophytic C. velox as a producer of antioxidant and genoprotective phenolic compounds that might be explored in the pharmaceutical sector (40).

Using different in vitro techniques, an analysis was performed to determine the antioxidant profile of TC stem extract. It was reported that TC stem extract has $(-)$ epicatechin. Along with other compounds, the presence of (-) epicatechin in TC can help to prevent different forms of flu as the natural and semi-synthetic derivatives of (-) epicatechin are known to have antiviral activity against the influenza virus (41).

\section{Hypoglycaemic and Hypolipidaemic properties}

A substantial decrease in blood glucose and brain lipids was caused by oral administration of aqueous TC root extract (TCre) to alloxan-diabetic rats. A spike in body weight, hepatic hexokinase and overall haemoglobin was caused by the extract. In diabetic rats, the root extract also decreases hepatic glucose-6phosphatase and serum phosphatase acid, alkaline phosphatase, and lactate dehydrogenase. Therefore, TCre has been reported to have hypolipidaemic and hypoglycaemic impact (42).

The hypolipidaemic effect of aqueous extracts of the roots of Tinospora cordifolia was examined. Important decreases in tissue and serum cholesterol, free fatty acids and phospholipids in alloxan diabetic rats resulted from administration of Tinospora cordifolia root extract ( 2.5 and $5.0 \mathrm{~g} / \mathrm{kg}$ body weight) for 6 weeks. The root extract demonstrated the strongest hypolipidaemic effect at a dosage of $5.0 \mathrm{~g} / \mathrm{kg}$ body weight. At 2.5 and $5.0 \mathrm{~g} / \mathrm{kg}$ body weight, Tinospora cordifolia roots had a greater effect than glibenclamide (43).

\section{Osteoblasts formation properties}

Osteoblasts are single-nucleated cells that synthesise bone. At a dosage of $25 \mu \mathrm{g} / \mathrm{ml}$, TC alcoholic extract has stimulated osteoblast formation, increased cell differentiation through osteoblast lineage, and increased bone-like matrix mineralization (44).

\section{Immunomodulatory Properties}

Isolation and characterisation of Tinospora cordifolia's immunomodulatory active compounds was performed. Seven immunomodulatory active compounds belonging to different classes were isolated and characterised, indicating that the synergistic effect of the group of compounds may be linked to the immunomodulatory activity of Tinospora cordifolia (45). The immunomodulatory function of three Tinospora spp. was evaluated and findings of the study showed that at a dosage of $300 \mathrm{mg} / \mathrm{kg}$, Neem-guduchi (Tinospora cordifolia developing on the tree of Azadirachta indica) possesses greater immunomodulatory potency (46).

\section{Immunostimulatory Properties}

Improving fish immunity by the application of natural immunostimulants will help to reduce the risk of diseases arising in aquaculture. A research was carried out to determine the growth-promoting and immunostimulatory activity of Tinospora cordifolia leaf powder on Amur carp fingerlings (Cyprinus carpio haematopterus Martens). Soybean meal, deoiled mustard cake, rice bran and vitamin-mineral mixture were combined to prepare the experimental diets. TC's leaf powder was 0.25 percent, 0.5 percent and 0.75 percent, respectively, introduced into three diets. Leaf powder from TC was not introduced into the control diet. Compared to control and all other diets, fingerlings supplied with diet containing 0.75 percent leaf powder of TC, achieved dramatically improved growth rate, feed conversion ratio and gross conversion efficiency. Study results showed that Tinospora cordifolia leaf powder in raising of Amur carp has important growth promotion and immunostimulatory ability (47).

The fish (Oreochromis mossambicus) was investigated for immunostimulatory effect of Tinospora Cordifolia leaf extract on non-specific immunity (neutrophil activity), specific immunity (antibody response) and disease tolerance against Aeromonas hydrophila. Ethanol and petroleum ether leaf extracts were used for the specific purpose of the study. Administered at doses of $0.8,8$ or $80 \mathrm{mg} / \mathrm{kg}$ body weight, both ethanol and petroleum ether extracts extended the peak primary antibody titers by one to three weeks. The secondary antibody response was improved by ethanol extract at a dose of $8 \mathrm{mg} / \mathrm{kg}$ and petroleum ether extract at doses of 0.8 or $8 \mathrm{mg} / \mathrm{kg}$. All the ethanol extract doses greatly increased the activity of neutrophils. Fish injected at a dosage of $8 \mathrm{mg} / \mathrm{kg}$ with petroleum ether or ethanol extract is shielded from laboratory contamination with virulent $\mathrm{A}$. hydrophila. The findings of the research show the ability for Tinospora cordifolia leaf extracts to be used as an immunoprophylactic agent to deter diseases in the aquaculture of finfish (48).

A investigation was carried to assess the impact of the water-soluble fraction of Tinospora cordifolia leaves on non-specific immunity and resistance to disease in fish (Oreochromis mossambicus). Fish were injected intraperitoneally $(0,6,60$ or $600 \mathrm{mg}$ water soluble fraction of TC) per $\mathrm{kg}$ of body weight. The serum lysozyme, antiprotease and natural haemolytic complement activities were greatly improved by all doses of water-soluble fraction of TC examined. Similarly, all doses of the water-soluble fraction used increased the function of cellular myeloperoxidase. The findings of the research specifically showed the disease tolerance and immunostimulatory characteristics of the 
TC leaf fraction and can therefore be used in finfish aquaculture as an immunoprophylactic (49).

\section{Protection from Skeletal Muscle Atrophy}

In order to investigate the in-vitro and in-vivo effectiveness and mechanism of TC in myogenic differentiation and skeletal muscle atrophy, the research was conducted to assess the probability of its use to counteract atrophy of skeletal muscle. For the determination of the myogenic potential and antiatrophic effects of Tinospora cordifolia water extract (TCE), C2C12 cell lines were used. Compared to control, TCE supplementation shows increased proliferation of lymphocytes and mediated myogenic differentiation of $\mathrm{C} 2 \mathrm{C} 12$ myoblasts by substantially increasing the length and thickness of myocytes. By substantially modulating lipid peroxidase, catalase, superoxide dismutase, glutathione peroxidase, and $\beta$ glucuronidase activities, TCE supplementation reduced oxidative stress and inflammatory reaction (50).

\section{Gastroprotective properties}

An experiment was carried out to determine the gastroprotective effect of Tinospora cordifolia-isolated epoxy clerodane diterpene (ECD) on indomethacininduced gastric ulcers in rats. The levels of PGE2, antiinflammatory cytokines and pro-angiogenic factors were significantly increased by ECD pretreatment. It can be concluded that ECD exercises its anti-ulcer action by enhancing the defensive components and reducing the offensive components (51).

\section{Antiosteoporotic properties}

The treatment choices for osteoporosis in postmenopausal women are limited due to a variety of side effects. The ability of TC stem ethanolic extract as an antiosteoporotic agent was investigated in this research.

An osteoprotective effect was observed in rats treated with TC extract at a dosage of $10 \mathrm{mg} / \mathrm{kg}$ body weight, as bone loss in the tibiae was slower than control. TC extract had estrogen-related effects in the bone, but not in reproductive organs.It can be concluded that TC extract has the ability to be used as an antiosteoporotic agent (52).

\section{Digestive enzyme properties}

Due to various reasons, plant enzymes are favoured over microbial enzymes in the pharmaceutical and food industries (53). While the digestive enzyme produced by fungal amylase (A. Oryzae) is believed to be harmless to consumer, the producer fungus itself may pose a variety of health risks to humans (54).It was also reported that the fungal amylase produces an inhalation allergen (55), and that its long-term use in a bakery induces allergic reactions in the workers (56).Despite the purification and characterization of a significant number of plant amylases $(57,58,59)$, none were found viable for commercial production (60). TC could be used as a plant digestive enzyme of commercial nature, with multiple benefits over the presently available fungal digestive amylase (61).

\section{Other properties}

A research was conducted to study the processes involved in the safety given to asthmatic mice by Tinospora cordifolia (TC) stem extract by oxidative stress control, pro-inflammatory mediator release and redox signalling. In the murine model of asthma, the findings indicate a beneficial role of TC extract against oxidative stress, pro-inflammatory mediator release and redox signalling. The TC extract reveals the medicinal ability for managing the asthmatic inflammation and other lung inflammatory complications (62).

An experiment was performed to investigate the activation of macrophages after in vitro TC therapy. The rate of macrophage pinocytosis, when measured by horseradish peroxidase uptake, was significantly increased compared to medium alone after treatment with Tinospora cordifolia. The macrophages showed increased phagocytosis after treatment with Tinospora cordifolia in E. coli (live infectious microorganisms) and in heat killed yeast (non-infective microorganisms). The findings show that, as analysed by cytochemical parameters, TC improves macrophage activation (63).

A research to determine the impact of dietary supplementation with Tinospora cordifolia on the biochemical, physico-morphological, antioxidant and serum testosterone levels of Muzzafarnagari rams was conducted. It was observed that TC supplementation had no major effect on rams' serum testosterone concentrations and physico-morphological/ biochemical semen properties. However, cholesterol, superoxide dismutase (SOD) and catalase concentrations in seminal plasma have been increased. It was reached to the conclusion that potential beneficial effects of supplementation with TC were to increase semen cholesterol levels and antioxidant enzymes, which could protect spermatozoa during cryopreservation and thus improves farm animals' fertility (64).

A small structural motif found in many proteins is an oligonucleotide binding fold (OB-fold). OB-fold was originally known for its binding properties of oligonucleotides or oligosaccharides. A protein has been identified and isolated from the TC stem that contains the OB-fold. These proteins have been discovered to be important for DNA replication, recombination, and repair (65).

The effect of aqueous and hydro alcoholic extracts of Tinospora cordifolia on the human mammary tumour cell line MCF-7 was studied. During the trial, cells were given extracts in three separate doses: $200 \mathrm{~g} / \mathrm{ml}, 400 \mathrm{~g} / \mathrm{ml}$, and $600 \mathrm{~g} / \mathrm{ml}$. Both extracts induced degenerative changes in the cell in a dosedependent way, with the maximal effect occurring at $600 \mathrm{~g} / \mathrm{ml}$. these results indicate that Tinospora cordifolia extracts may be used as an antiproliferative agent in mammary tumours (66).

An experiment was undertaken to see whether dietary TC supplementation could help minimise the risk of lactic acidosis in goats. Complete protozoa count, lactic acid concentration, and rumen fluid $\mathrm{pH}$ were used as markers to determine the TC stem's ability to relieve symptoms. The results of the study revealed 
that supplementing goats with $T$. cordifolia stem would help them stop lactic acidosis (67).

The therapeutic effect of Tinospora cordifolia stem extract administration for mastitis treatment was investigated. Cows supplied with TC extract had a better recovery rate than those administered with antibiotics alone. As a result, TC may be combined with intramammal antibiotic treatment to enhance the mastitis cure rates (68).

The biodiesel's oxidative stability is a crucial parameter for fuel quality that determines not only the fuel's composition but also engine's efficiency. In order to see the effect of TC stem extract as an antioxidant additive for Karanja biodiesel, a research was conducted. The TC stem extract has been reported to serve as an affordable, environmentally safe and nontoxic replacement for synthetic antioxidants (69).

It was examined to see how dietary supplementation of Tinospora cordifolia stem powder and Withania somnifera root powder had influenced the broilers' growth efficiency. Supplementing broilers with Tinospora cordifolia stem powder and Withania somnifera root powder have dramatically improved average body weights. It is also speculated that using Tinospora cordifolia and Withania somnifera in the diet may help to increase growth efficiency and decrease mortality in broilers (70).

An experiment was carried out to assess the presence of IROS (intracellular reactive oxygen species) in the peripheral blood of patients with severe polyarthralgia following Chikungunya infection, as well as the ability of Tinospora cordifolia leaf extract to scavenge certain free radicals in the patient's peripheral blood mononuclear cells (PBMC). In comparison to healthy people, Chikungunya patient's PBMC had twotimes higher IROS. Ex-vivo treatments of PBMC of Chikungunya patient with an ethanolic extract of Tinospora cordifolia leaf $(1 \mathrm{~g} / \mathrm{mL})$ greatly reduced IROS. In patients with persistent polyarthralgia, Chikungunya infection induces a high degree of IROS, which was greatly reduced by ex vivo therapy with Tinospora cordifolia leaf extract (71).

\section{Effect of TC supplementation on food properties}

An experiment was carried out to develop functional food as cookies by incorporating the TC stem powder. TC stem powder was used to make cookies by its addition at the rate of $2,4,8,10$, and $12 \%$. The addition of 0 to 12 percent TC powder to cookies causes a gradual drop in the sensory parameters. Up to 8 percent of the maximum admissible TC powder concentration, the cookies formulation is reported sensory acceptable. The use of TC in cookies has resulted in an increase in the protein, iron, copper, zinc and antioxidants potential, while the fat content has reduced. With respect to functional properties, produced cookies have proven to be better than regular control cookies (72).

Usage of 2.5, 5.0 and 7.5 percent dried Tinospora cordifolia leaf powder (DTLP) for the nutritional and organoleptic properties of cookies; rheological properties of wheat flour are tested. An increase in DTLP quantity from 0 to 7.5 percent had increased the farinograph absorption of water, increased stiffness, decreased stability of the dough, increased temperature of amylograph gelatinization, decreased peak viscosity, decreased springiness and cohesiveness of cookie dough; increased breaking strength and decreased spread ratio of the cookie. Sensory analysis proves that $5 \%$ DTLP embedded cookies were acceptable. The addition of DTLP had enhanced the cookie's amount of protein, calcium, dietary fibre, iron, $\beta$-carotene and radical scavenging activity. In order to boost the nutritional properties of cookies, the findings of the study demonstrated the likelihood of using DTLP (73).

Spray drying at the outlet temperature $90^{\circ} \mathrm{C}$ was done to prepare the leaf and stem extract powders of TC. The antioxidant activity of TC leaf extract powder, obtained from spray drying, was observed to be more stable than that of stem extract powder. The total percent polyphenols in spray dried leaf powder at $90^{\circ} \mathrm{C}$ outlet temperature was found to be significantly higher than stem powder. Such spray-dried powders of TCL/ TCS extracts can be used in food product formulations having different health benefits (74).

\section{Conflict of interest - Nil}

The authors declare that they have no known competing financial interests or personal relationships that could have appeared to influence the work reported in this review paper.

\section{Conclusion}

India is the home of diverse range of medicinal plants that are traditionally used in disease management. This review paper illustrates strong basis for the Tinospora cordifolia use in disease control. In this article, the pharmacological mechanism of action of Tinospora cordifolia is depicted in such a way that it will help to encourage a more realistic use of it in herbal medicinal/ food formulations in order to produce the desired outcomes. It can be concluded that Tinospora cordifolia utilization in conventional pharmaceutical preparations and in nutraceuticals may be better harnessed, laying the foundation for further integration into the healthcare system.

\section{References}

1. Sinha, K., Mishra, N. P., Singh, J., \& Khanuja, S. P. S. (2004). Tinospora cordifolia (Guduchi), a reservoir plant for therapeutic applications: A Review.

2. Bhandari, C. R. (Ed.). (1953). Vanaushadhi Chandrodaya. Chowkhamba Sanskrit Series Office.

3. Patwardhan, B. \& Gautam, M (2005). Drug Discov Today; 10:495- 502. https://doi.org/10.1016/ S1359-6446(04)03357-4

4. Patil, M., Patki, P., Kamath, H. V., \& Patwardhan, B. (1997). Antistress activity of Tinospora cordifolia (wild) miers. Indian Drugs Bombay, 34, 211-215.

5. Pharmacopoeia, I. (2007). The Indian pharmacopoeia commission. Central Indian Pharmacopoeia 
Laboratory, Ministry of Health and Family Welfare, Govt of India, Sector, 23.

6. Premila, M. S. (2006). Ayurvedic herbs: a clinical guide to the healing plants of traditional Indian medicine. Psychology Press.

7. Pandey, G. (2002). Dravyaguna Vijnana .Varuanasi: Krishnadas Academy; Second Edition pp. Vol. 1 pp. 697-710.

8. Krishna, K., Jigar, B., \& Jagruti, P. (2009). Guduchi (Tinospora cordifolia): Biological and Medicinal properties, a review. The Internet Journal of Alternative Medicine, 6(2), 1-10.

9. Badar, V. A., Thawani, V. R., Wakode, P. T., Shrivastava, M. P., Gharpure, K. J., Hingorani, L. L., \& Khiyani, R. M. (2005). Efficacy of Tinospora cordifolia in allergic rhinitis. Journal of ethnopharmacology, 96(3), 445-449. https://doi.org/ 10.1016/j.jep.2004.09.034

10. Warrier, P. K., Nambiar, V. P. K., \& Ramankutty, C. (1996). Indian medicinal plants: a compendium of 500 species: Orient Longman Ltd. Chennai, 3, 38-90.

11. Lalramnghinglova, H. (2003). Ethno-medicinal plants of Mizoram. Bishen Singh Mahenda Pal Singh.

12. Sood, S. K., Parmar, S., \& Lakhanpal, T. N. (2005). Ethnic plants of India used in cancer cure--a compendium. Bishen Singh Mahendra Pal Singh.

13. Singh, S. S., Pandey, S. C., Srivastava, S., Gupta, V. S., Patro, B., \& Ghosh, A. C. (2003). Chemistry and medicinal properties of Tinospora cordifolia (Guduchi).

14. Sinha, K., Mishra, N. P., Singh, J., \& Khanuja, S. P. S. (2004). Tinospora cordifolia (Guduchi), a reservoir plant for therapeutic applications: A Review. http://hdl.handle.net/123456789/9359

15. Soni, H., Nayak, G., Patel, S. S., Mishra, K., Singh, R. V., \& Singhai, A. K. (2011). Pharmacognostic studies of the leaves of Tinospora cordifolia. IJPI'SJ Pharm Herb Formul, 1(3).

16. Chintalwar, G., Jain, A., Sipahimalani, A., Banerji, A., Sumariwalla, P., Ramakrishnan, R., \& Sainis, K. (1999). An immunologically active arabinogalactan from Tinospora cordifolia. Phytochemistry, 52(6), $1089-1093$. https://doi.org/10.1016/ S0031-9422(99)00386-6

17. Bisset, N. and Nwaiwu, J. (1983). Planta Med, 48, 275-279. DOI: $10.1055 / \mathrm{s}-2007-969933$

18. Fowler, M. J. (2008). Microvascular and macrovascular complications of diabetes. Clinical diabetes, 26(2), 77-82. https://doi.org/10.2337/ diaclin.26.2.77

19. Fouad, M., Salem, I., Elhefnawy, K., Raafat, N., \& Faisal, A. (2020). MicroRNA-21 as an early marker of nephropathy in patients with type 1 diabetes. Indian journal of nephrology, 30(1), 21. doi: 10.4103/ijn.IJN_80_19

20. Agrawal, S. S., Naqvi, S., Gupta, S. K., \& Srivastava, S. (2012). Prevention and management of diabetic retinopathy in STZ diabetic rats by Tinospora cordifolia and its molecular mechanisms. Food and Chemical Toxicology, 50(9), 3126-3132. https:// doi.org/10.1016/j.fct.2012.05.057
21. Joladarashi, D., Chilkunda, N. D., \& Salimath, P. V. (2012). Tinospora cordifolia consumption ameliorates changes in kidney chondroitin sulphate/ dermatan sulphate in diabetic rats. Journal of nutritional science, 1. DOI: https://doi.org/10.1017/ jns. 2012.6

22. Rawal, A., Muddeshwar, M., \& Biswas, S. (2004). Effect of Rubia cordifolia, Fagonia cretica linn, and Tinospora cordifolia on free radical generation and lipid peroxidation during oxygen-glucose deprivation in rat hippocampal slices. Biochemical and biophysical research communications, 324(2), 588-596. https://doi.org/10.1016/j.bbrc.2004.09.094

23. Karamalakova, Y., Nikolova, G., Adhikari, M., Stoev, S., Agarwal, P., Gadjeva, V., \& Zhelev, Z. (2018). Oxidative-protective effects of Tinospora cordifolia extract on plasma and spleen cells after experimental ochratoxicosis. Comparative Clinical Pathology, 27(6), 1487-1495. https://doi.org/10.1007/ s00580-018-2761-y

24. Reddy, S. S., Ramatholisamma, P., Karuna, R., \& Saralakumari, D. (2009). Preventive effect of Tinospora cordifolia against high-fructose dietinduced insulin resistance and oxidative stress in male Wistar rats. Food and chemical toxicology, 47(9), 2224-2229. https://doi.org/ 10.1016/j.fct.2009.06.008

25. Grover, J. K., Vats, V., \& Rathi, S. S. (2000). Antihyperglycemic effect of Eugenia jambolana and Tinospora cordifolia in experimental diabetes and their effects on key metabolic enzymes involved in carbohydrate metabolism. Journal of Ethnopharmacology, 73(3), 461-470. https://doi.org/ 10.1016/S0378-8741(00)00319-6

26. Patel, M. B., \& Mishra, S. (2011). Hypoglycemic activity of alkaloidal fraction of Tinospora cordifolia. Phytomedicine, 18(12), 1045-1052. https://doi.org/10.1016/j.phymed.2011.05.006

27. Grover, J. K., Vats, V., Rathi, S. S., \& Dawar, R. (2001). Traditional Indian anti-diabetic plants attenuate progression of renal damage in streptozotocin induced diabetic mice. Journal of Ethnopharmacology, 76(3), 233-238. https://doi.org/ 10.1016/S0378-8741(01)00246-X

28. Agarwal, A., Malini, S., Bairy, K. L., \& Rao, M. S. (2002). Effect of Tinospora cordifolia on learning and memory in normal and memory deficit rats. Indian journal of pharmacology, 34(5), 339-349.

29. Utpalendu, J., Chattopadhyay, R. N., \& Badri, P. S. (1999). Preliminary studies on anti-inflammatory activity of Zingiber officinale Rosc., Vitex negundo Linn and Tinospora cordifolia (willid) Miers in albino rats. Indian journal of pharmacology, 31(3), 232.

30. Reddi, K. K., \& Tetali, S. D. (2019). Dry leaf extracts of Tinospora cordifolia (Willd.) Miers attenuate oxidative stress and inflammatory condition in human monocytic (THP-1) cells. Phytomedicine, 61, 152831 . https://doi.org/10.1016/ j.phymed.2019.152831

31. Sunanda, S. N., Desai, N. K., \& Ainapure, S. S. (1986). Antiallergic properties of Tinospora 
cordifolia in animal models. Indian Journal of Pharmacology, 18(4), 250.

32. Diwanay, S., Chitre, D., \& Patwardhan, B. (2004). Immunoprotection by botanical drugs in cancer chemotherapy. Journal of ethnopharmacology, 90(1), 49-55. https://doi.org/10.1016/j.jep.2003.09.023

33. Bala, M., Pratap, K., Verma, P. K., Singh, B., \& Padwad, Y. (2015). Validation of ethnomedicinal potential of Tinospora cordifolia for anticancer and immunomodulatory activities and quantification of bioactive molecules by HPTLC. Journal of ethnopharmacology, 175, 131-137. https://doi.org/ 10.1016/j.jep.2015.08.001

34. Leyon, P. V., \& Kuttan, G. (2004). Inhibitory effect of a polysaccharide from Tinospora cordifolia on experimental metastasis. Journal of ethnopharmacology, 90(2-3), 233-237. https:// doi.org/10.1016/j.jep.2003.09.046

35. Jagetia, G. C., Nayak, V., \& Vidyasagar, M. S. (1998). Evaluation of the antineoplastic activity of guduchi (Tinospora cordifolia) in cultured HeLa cells. Cancer letters, 127(1-2), 71-82. https://doi.org/ 10.1016/S0304-3835(98)00047-0

36. Singh, S. M., Singh, N., \& Shrivastava, P. (2006). Effect of alcoholic extract of Ayurvedic herb Tinospora cordifolia on the proliferation and myeloid differentiation of bone marrow precursor cells in a tumor-bearing host. Fitoterapia, 77(1), 1-11. https:// doi.org/10.1016/j.fitote.2005.05.002

37. Mathew, S., \& Kuttan, G. (1999). Immunomodulatory and antitumour activities of Tinospora cordifolia. Fitoterapia, 70(1), 35-43. https://doi.org/10.1016/S0367-326X(98)00017-3

38. Badar, V. A., Thawani, V. R., Wakode, P. T., Shrivastava, M. P., Gharpure, K. J., Hingorani, L. L., \& Khiyani, R. M. (2005). Efficacy of Tinospora cordifolia in allergic rhinitis. Journal of ethnopharmacology, 96(3), 445-449. https://doi.org/ 10.1016/j.jep.2004.09.034

39. Prince, P. S. M., \& Menon, V. P. (1999). Antioxidant activity of Tinospora cordifolia roots in experimental diabetes. Journal of ethnopharmacology, 65(3), $277-281$. https://doi.org/10.1016/ S0378-8741(98)00164-0

40. Singh, B., Sharma, P., Kumar, A., Chadha, P., Kaur, R., \& Kaur, A. (2016). Antioxidant and in vivo genoprotective effects of phenolic compounds identified from an endophytic Cladosporium velox and their relationship with its host plant Tinospora cordifolia. Journal of ethnopharmacology, 194, 450-456. https://doi.org/10.1016/j.jep.2016.10.018

41. Pushp, P., Sharma, N., Joseph, G. S., \& Singh, R. P. (2013). Antioxidant activity and detection of (-) epicatechin in the methanolic extract of stem of Tinospora cordifolia. Journal of food science and technology, 50(3), 567-572. https://doi.org/10.1007/ s13197-011-0354-8

42. Stanely, P., Prince, M., \& Menon, V. P. (2000). Hypoglycaemic and other related actions of Tinospora cordifolia roots in alloxan-induced diabetic rats. Journal of ethnopharmacology, 70(1),
9-15. ht tps://doi.org/10.1016/ S0378-8741(99)00136-1

43. Prince, P. S. M., Menon, V. P., \& Gunasekaran, G. (1998). Hypolipidaemic action of Tinospora cordifolia roots in alloxan diabetic rats. Journal of Ethnopharmacology, 64(1), 53-57. https://doi.org/ 10.1016/S0378-8741(98)00106-8

44. Abiramasundari, G., Sumalatha, K. R., \& Sreepriya, M. (2012). Effects of Tinospora cordifolia (Menispermaceae) on the proliferation, osteogenic differentiation and mineralization of osteoblast model systems in vitro. Journal of ethnopharmacology, 141(1), 474-480. https://doi.org/ 10.1016/j.jep.2012.03.015

45. Aranha, I., Clement, F., \& Venkatesh, Y. P. (2012). Immunostimulatory properties of the major protein from the stem of the Ayurvedic medicinal herb, guduchi (Tinospora cordifolia). Journal of ethnopharmacology, 139(2), 366-372. https://doi.org/ 10.1016/j.jep.2011.11.013

46. Narkhede, A. N., Jagtap, S. D., Kasote, D. M., Kulkarni, O. P., \& Harsulkar, A. M. (2014). Comparative immunomodulation potential of Tinospora cordifolia (Willd.) Miers ex Hook. F., Tinospora sinensis (Lour.) Merrill and Tinospora cordifolia growing on Azadirachta indica A. Juss. http://hdl.handle.net/123456789/29299

47. Dubey, M. K., Khati, A., \& Chauhan, R. S. (2016). Immunostimulatory and growth promoting potential of Tinospora cordifolia (Thunb.) Miers on fingerlings of Amur carp. http://nopr.niscair.res.in/handle/123456789/35693

48. Sudhakaran, D. S., Srirekha, P., Devasree, L. D., Premsingh, S., \& Michael, R. D. (2006). Immunostimulatory effect of Tinospora cordifolia Miers leaf extract in Oreochromis mossambicus. http://hdl.handle.net/123456789/6598

49. Alexander, C. P., Kirubakaran, C. J. W., \& Michael, R. D. (2010). Water soluble fraction of Tinospora cordifolia leaves enhanced the non-specific immune mechanisms and disease resistance in Oreochromis mossambicus. Fish \& shellfish immunology, 29(5), 765-772. https://doi.org/10.1016/j.fsi.2010.07.003

50. Sharma, B., Dutt, V., Kaur, N., Mittal, A., \& Dabur, R. (2020). Tinospora cordifolia protects from skeletal muscle atrophy by alleviating oxidative stress and inflammation induced by sciatic denervation. Journal of ethnopharmacology, 254, 112720. https://doi.org/ 10.1016/j.jep.2020.112720

51. Antonisamy, P., Dhanasekaran, M., Ignacimuthu, S., Duraipandiyan, V., Balthazar, J. D., Agastian, P., \& Kim, J. H. (2014). Gastroprotective effect of epoxy clerodane diterpene isolated from Tinospora cordifolia Miers (Guduchi) on indomethacin-induced gastric ulcer in rats. Phytomedicine, 21(7), 966-969. https://doi.org/10.1016/j.phymed.2014.02.010

52. Kapur, P., Jarry, H., Wuttke, W., Pereira, B. M. J., \& Seidlova-Wuttke, D. (2008). Evaluation of the antiosteoporotic potential of Tinospora cordifolia in female rats. Maturitas, 59(4), 329-338. https:// doi.org/10.1016/j.maturitas.2008.03.006 
53. Jach, G., Soezer, N., Schullehner, K., Lalla, B., Welters, P., \& Mueller, A. (2010). Phytomining of plant enzymes for biotechnological use of fats and oils. European journal of lipid science and technology, 112(1), 75-86. https://doi.org/10.1002/ ejlt.200900100

54. Patel, A. K., Singhania, R. R., \& Pandey, A. (2017). Production, purification, and application of microbial enzymes. In Biotechnology of Microbial Enzymes (pp. 13-41). Academic Press. https:// doi.org/10.1016/B978-0-12-803725-6.00002-9

55. Baur, X., Fruhmann, G., Haug, B., Rasche, B., Reiher, W., \& Weiss, W. (1986). Role of Aspergillus amylase in baker's asthma. The Lancet, 327(8471), 43. DOI: https://doi.org/10.1016/ S0140-6736(86)91924-0

56. Smith, T. A., Lumley, K. P. S., \& Hui, E. H. K. (1997). Allergy to flour and fungal amylase in bakery workers. Occupational Medicine, 47(1), 21-24. https://doi.org/10.1093/occmed/47.1.21

57. Beers, E. P., \& Duke, S. H. (1990). Characterization of $\alpha$-amylase from shoots and cotyledons of pea ( Pisum sativum L.) seedlings. Plant Physiology, 92(4), 1154-1163. https://doi.org/ 10.1104/pp.92.4.1154

58. Koshiba, T., \& Minamikawa, T. (1981). Purification by affinity chromatography of $\alpha$-amylase - a main amylase in cotyledons of germinating Vigna mungo seeds. Plant and cell physiology, 22(6), 979-987. https://doi.org/10.1093/oxfordjournals.pcp.a076261

59. Masuda, H., Takahashi, T., \& Sugawara, S. (1987). Purification and properties of starch hydrolyzing enzymes in mature roots of sugar beets. Plant physiology, 84(2), 361-365. https://doi.org/10.1104/ pp.84.2.361

60. Doehlert, D. C., \& Duke, S. H. (1983). Specific determination of $\alpha$-amylase activity in crude plant extracts containing $\beta$-amylase. Plant Physiology, 71(2), 229-234. https://doi.org/10.1104/ pp.71.2.229

61. Mukherjee, A., Sengupta, S., Ray, L., \& Sengupta, S. (2012). Evaluation of Tinospora cordifolia amylase as a commercial digestive enzyme of plant origin. Journal of herbs, spices \& medicinal plants, 18(1), 58-76. https://doi.org/ 10.1080/10496475.2011.649515

62. Tiwari, M., Dwivedi, U. N., \& Kakkar, P. (2014). Tinospora cordifolia extract modulates COX-2, iNOS, ICAM-1, pro-inflammatory cytokines and redox status in murine model of asthma. Journal of ethnopharmacology, 153(2), 326-337. https://doi.org/ 10.1016/j.jep.2014.01.031

63. More, P., \& Pai, K. (2017). Effect of Tinospora cordifolia (Guduchi) on the phagocytic and pinocytic activity of murine macrophages in vitro. http:// nopr.niscair.res.in/handle/123456789/39720
64. Jayaganthan, P., Perumal, P., Balamurugan, T. C., Verma, R. P., Singh, L. P., Pattanaik, A. K., \& Kataria, M. (2013). Effects of Tinospora cordifolia supplementation on semen quality and hormonal profile in rams. Animal reproduction science, 140(1-2), 47-53. https://doi.org/10.1016/ j.anireprosci.2013.05.003

65. Amir, M., Haque, M. A., Dar, M. A., Islam, A., Ahmad, F., \& Hassan, M. I. (2016). Purification and characterization of oligonucleotide binding (OB)fold protein from medicinal plant Tinospora cordifolia. Journal of Chromatography B, 1008, 38-44. https://doi.org/10.1016/j.jchromb.2015.11.016

66. Priya, M. S., Venkateswaran, K. V., \& Vijayanand, T. (2014). Effect of Tinospora cordifolia on MCF-7 cell morphology.

67. Adgale A, Adkine A, Adlak S, Adsul N, Ap A, Agarkar Y, ..... \& Ali M (2013), Adak A.

68. Ranjan, R., D. Swarup. and R.C. Patra (2007). Ameliorative potential of stem extracts of Tinospora cordifolia in bovine clinical mastitis. Indian. J. Ani. Sci., 77 (10): 937-939.

69. Kumar, D., \& Singh, B. (2018). Tinospora cordifolia stem extract as an antioxidant additive for enhanced stability of Karanja biodiesel. Industrial Crops and Products, 123, 10-16. https://doi.org/10.1016/ j.indcrop.2018.06.049

70. Joshi, S. S., Ingle, P. B., Bhagwat, S. R., Pawar, M. M., Prajapati, K. B., \& Kulkarni, R. C. (2015). Effect of dietary addition of ashwagandha (Withania somnifera) and guduchi (Tinospora cordifolia) powder on broiler performance. Indian journal of animal sciences, 85(12), 1358-1361.

71. Banerjee, N., Saha, B., \& Mukhopadhyay, S. (2018). Intracellular ROS generated in chikungunya patients with persisting polyarthralgia can be reduced by Tinospora cordifolia leaf extract. Virusdisease, 29(3), 375-379. https://doi.org/10.1007/s13337-018-0465-1

72. Tyagi, P., Chauhan, A. K., \& Singh, S. N. (2020). Sensory acceptability of value added cookies incorporated with Tinospora cordifolia (TC) stem powder; improvement in nutritional properties and antioxidant potential. Journal of Food Science and Technology, 1-7. https://doi.org/10.1007/ s13197-020-04325-5

73. Sharma, P., Velu, V., Indrani, D., \& Singh, R. P. (2013). Effect of dried guduchi (Tinospora cordifolia) leaf powder on rheological, organoleptic and nutritional characteristics of cookies. Food Research International, 50(2), 704-709. https:// doi.org/10.1016/j.foodres.2012.03.002

74. Sarala, M., Velu, V., Anandharamakrishnan, C., \& Singh, R. P. (2012). Spray drying of Tinospora cordifolia leaf and stem extract and evaluation of antioxidant activity. Journal of food science and technology, 49(1), 119-122. https://doi.org/10.1007/ s13197-011-0364-6. 